\title{
SYSTEMATIC LITERATURE REVIEW : PENGGUNAAN KAHOOT PADA PEMBELAJARAN MATEMATIKA
}

\author{
${ }^{1}$ Aan Putra, ${ }^{2}$ Kesi Afrilia \\ ${ }^{1,2}$ Institut Agama Islam Negeri Kerinci, Jalan Muradi, Sungai Penuh, 37112, Indonesia \\ Email: aanputra283@iainkerinci.ac.id
}

Abstrak

Perlunya melakukan sebuah inovasi untuk menunjang pembelajaran matematika yang dilakukan secara daring. Salah satu inovasi yang bisa dilakukan yaitu melalui media pembelajaran. Media pembelajaran dapat digunakan untuk membangun semangat dan motivasi belajar peserta didik yang dapat meningkatkan hasil belajar. Penelitian ini bertujuan untuk melakukan kajian literatur terkait dengan penggunaan Kahooot pada pembelajaran matematika. Metode penelitian yang dipilih dalam penelitian ini adalah metode SLR (Systematic Literature Review). Pengumpulan data dilakukan dengan mendokumentasi dan merevieu semua artikel terkait aplikasi Kahoot yang diterbitkan dalam kurun waktu 2012-2020. Artikel yang digunakan pada penelitian ini sebanayak 27 artikel jurnal nasional terakreditasi yang diperoleh dari database Google Schoolar menggunakan aplikasi Publish atau Perish. Berdasarkan penelitian ini didapatkan bahwa Kahoot dapat meningkatkan hasil, semangat belajar dan keefektifan peserta didik dalam pembelajaran matematika.

Kata kunci: Kahoot, Pembelajaran Matematika, Systematic Literature Review

\begin{abstract}
The need to make an innovation to suport mathematics learning that is carried out online. One of the inovations that can be done is trough learning media. Learning media can be used to build ethuasiasm and motivation for students to learn which can improve learning learning outcomes. This study aims to conduct a literature review related to the use of Kahooot in mathematics learning. The research method chosen in this study is the SLR (Systematic Literature Review) method. Data collection was carried out by documenting and reviewing all articles related to the Kahoot application published in the 2012-2020 period. The articles used in this study were 27 articles from accredited national journals obtained from the Google Schoolar database using the Publish or Perish application. Based on this research, it was found that Kahoot could improve the result, ethusiasm for learning and the effectivennes of students in learning mathematics.
\end{abstract}

Keywords : Kahoot, Mathematics Learning, Systematic Literature Review

\section{PENDAHULUAN}

Pandemi Covid-19 melanda di seluruh negeri yang ada di belahan dunia. Corona Virus Disease 2019 (Covid-19) ini berasal dari Wuhan, Provinsi Hubei Cina dan telah menyebar dengan cepat ke seluruh dunia. Corona Virus atau Covid-19 merupakan keluarga besar dari virus yang dapat menyebabkan penyakit dengan ditandai dengan gejala umum antara lain gangguan pernapasan akut seperti demam, sesak napas, dan batuk yang menyerang sistem pernapasan seperti hidung, tenggorokan, dan paru-paru. Covid-19 merupakan penyakit menular yang dapat menyebar secara langsung maupun secara tidak langsung dari satu orang ke orang yang lain. Melihat penyebarannya yang sangat cepat, pada tanggal 11 Maret 2020 World Health Organization (WHO) telah menetapkan Covid-19 sebagai pandemi global (Dewi, 2020; Melinda \& Lazwardi, 2020; Mustakim, 2020; Rigianti, 2020).

Di tahun 2020 tepatnya menginjak bulan Maret Indonesia dilanda penyebaran Covid-19 (Nurhayati, 2020; Patimah, Lyesmaya, \& Maula, 2020). Berkaitan dengan adanya wabah Covid-19 pada tahun 2020, pemerintah kemudian mengambil kebijakan dengan mengeluarkan himbauan agar melakukan pembelajaran dari rumah. Pada tanggal 24 Maret 2020 Menteri Pendidikan dan Kebudayaan Republik Indonesia mengeluarkan Surat Edaran Nomor 4 Tahun 2020 tentang pelaksanaan kebijakan pendidikan dalam masa darurat penyebaran Covid-19(Dewi, 2020). Masa 
darurat pandemi ini mengharuskan pergantian sistem pembelajaran yang awalnya tatap muka beralih menjadipembelajaran daring. Kebijakan ini diambil agar proses pembelajaran tetap berlangsung (Sintema, 2020).

Pada awalnya istilah model pengajaran daring hanya digunakan untuk menggambarkan sistem belajar dengan memanfaatkan teknologi internet berbasis komputer (TIK). Akan tetapi seiring dengan perkembangan zaman pengajaran daring ini tidak hanya bisa melalui komputer namun sudah bisa diakses melalui smartphone (Rosyid, Thohari, \& Lismanda, 2020). Berdasarkan Kamus Besar Bahasa Indonesia (KBBI) bahwa sistem pembelajaran daring merupakan sebuah sistem pembelajaran dengan menggunakan jaringan internet (e-learning) (Hasanah, 2020).

Pembelajaran daring merupakan suatu proses pembelajaran elektronik dengan memanfaatkan teknologi komunikasi dan informasi, misalnya internet (Abidin, Rumansyah, \& Arizona, 2020; Suhery, Putra, \& Jasmalinda, 2020). Hal tersebut sejalan dengan (Alessandro, 2018) bahwa pembelajaran daring akan melibatkan unsur teknologi sebagai sarana dan jaringan sebagai sistem. Selanjutnya, (Fitriyani, Fauzi, \& Sari, 2020) juga mengemukakan bahwa pembelajaran daring merupakan sebuah inovasi dalam pendidikan yang melibatkan unsur teknologi komunikasi dan informasi dalam suatu pembelajaran.

Namun faktanya, menjelaskan bahwa peralihan pembelajaran konvensional ke pembelajaran daring bukanlah hal yang mudah terutama pada mata pelajaran matematika. Hal ini dikarenakan sampai saat ini siswa masih menganggap bahwa matematika itu mata pelajaran yang sulit. Hal tersebut sejalan dengan kenyataan dilapangan bahwa terlihat jelas pembelajaran matematika belum mampu tercapai secara maksimal. Siswa berasumsi bahwa matematika merupakan suatu mata pelajaran yang sulit untuk dipahami dikarenakan proses pembelajarannya kurang membangkitkan kreaktifitas siswa sehingga siswa masih berfikirdan memiliki rasa malas untuk mempelajari matematika. Hal inilah yang menjadi faktor mengapa pembelajaran matematika masih tergolong rendah (Mustakim, 2020; Purwasih, Aripin, \& Fitrianna, 2018; Siregar, 2017)

Pembelajaran merupakan suatu proses internalisasi ilmu pengetahuan yang terjadi di dalam kelas. Proses pembelajaran ini terdapat aktivitas siswa sebagai pelajar dan guru sebagai pengajar yang didukung oleh media, alat, metode, serta bahan ajar yang sesuai dengan kebutuhan di kelas (Syarifudin, 2020). Pembelajaran matematika merupakan serangkaian kegiatan yang telah direncanakan untuk membangun keterlibatan peserta didik untuk aktif dalam artian memiliki keinginan untuk membangun potensi tentang matematika (Betyka, Putra, \& Erita, 2019; Sartika \& Octafiani, 2019). Hal ini diperkuat oleh pernyataan (Afifah, 2012) bahwa pembelajaran matematika merupakan suatu proses dan usaha untuk membantu siswa dalam membangun pengetahuannya.

Di tengah pandemi seperti ini, untuk mendukung pembelajaran berbasis online atau daring. Ada beberapa aplikasi yaang dapat digunakan seperti Google Classsroom, Edmodo, Zoom. Selain itu, untuk mengevaluasi pembelajaran juga didukung oleh beberapa aplikasi berbasis internet seperti Kahoot, Google Form, dan Quizziz. Tidak dapat dipungkiri aplikasi dan sumber belajar yang berbasis teknologi informasi dan komunikasi (TIK) maupun berbasis internet terbukti mampu memperkaya proses pembelajaran dalam hal peningkatan kreaktivitas, minat dan motivasi siswa (C. S. Lin \& Wu, 2016; M. H. Lin, Chen, \& Liu, 2017; Y. W. Lin, Tseng, \& Chiang, 2017).

Selanjutnya, (Dewi, 2020) juga mengemukakan bahwa ada beberapa aplikasi yang mendukung dalam proses pembelajaran daring seperti zoom, live chat, telepon atau live, classroom, maupun melalui whatsapp group. Kemudian (Handarini \& Wulandari, 2020) juga mengemukakan bahwa ada beberapa aplikasi juga yang memabantu dalam proses pembelajaran daring seperti web blog, zoom, whatsapp, dan lain-lain. Begitupun dengan Kementrian Pendidikan dan Kebudayaan (Kemendikbud) juga menyediakan aplikasi atau platform yang bisa diakses pelajar untuk mendukunng proses pembelajaran dari rumah diantaranya, Rumah Belajar, Meja Kita, Icando, 
Indonesianx, Google for Education, Kelas Pintar, Microsoft Office 365, Quipper School, Ruang Guru, Sekolahmu, Zenius, dan Cisco Webex.

Dengan kondisi seperti ini, sebagai guru harus mampu memilih media pembelajaran yang tepat untuk digunakan dalam pembelajaran daring. Hal ini dikarenakan media pembelajaran berguna untuk membangkitkan motivasi belajar, dan kreaktifitas siswa (Wibawanto, 2017). Untuk membantu dalam proses pembelajaran daring dibutuhkan media yang efektif untuk meningkatkan hasil belajar peserta didik. Salah satu inovasi media pembelajaran yang dapat digunakan berupa media permainan media ini dapat meningkatkan motivasi belajar peserta didik sehingga hasil belajar peserta didik dapat meningkat.

Hasil penelitian Sartika \& Octafiani, 2019 menunjukkan bahwa aplikasi Kahoot sangat layak digunakan sebagai alat evaluasi. Dikarenakan aplikasi Kahoot sangat membantu pembelajaran agar lebih menarik, tidak membosankan, dan lebih meningkatkan kreaktifitas dan keaktifan siswa. Kahoot merupakan aplikasi online dimana kita bisa membuat kuis dan menyajikannya dalam bentuk permainan, adapun poin yang diberikan dalam untuk jawaban yang benar bisa dilihat langsung oleh peserta didik. Pembelajaran berbasis permainan ini memiliki potensi untuk menjadi alat yang efektif karena merangsang komponen visual dan verbal peserta didik(Iwamoto, Hargis, Taitano, \& Vuong, 2017).

Penggunaan Kahoot terbukti efektif dalam proses pembelajaran secara daring. Hal ini membuat peneliti tertarik untuk melakukam kajian literatur terhadap penggunaan Kahoot pada pembelajaran matematika secara daring. Sehingga akhirnya peneliti dapat menerapkan media pembelajaran Kahoot ini pada pembelajaran matematika.

\section{METODE PENELITIAN}

Systematic Literature Review (SLR) ini dilakukan dengan mengidentifikasi, mengkaji, mengevaluasi, serta menafsirkan semua penelitian yang tersedia. Dengan metode ini peneliti melakukan reviu dan mengidentifikasi jurna-jurnal secara terstruktur yang pada setiap prosesnya mengikuti langkah-langkah yang telah ditetapkan (Triandini, Jayanatha, Indrawan, Werla Putra, \& Iswara, 2019). Untuk merampungkan penelitian ini, peneliti mengumpulkan artikel jurnal pada database Google Schoolar dengan bantuan aplikasi Publish orn Perish. Kata kunci adalah Kahoot, dan Pembelajaran Matematika. Artikel yang dikumpulkan hanya artikel yang dipublikasikan dalam rentang waktu 2012 hingga 2020. Dari berbagai artikel, peneliti memilih 27 artikel terkait erat dengan kata kunci yang digunakan.

Langkah selanjutnya, peneliti mengelompokkan artikel-artikel yang ada Kahoot baik berhubungan dengan pembelajaran matematika maupun hasil belajar secara umum. Metadata artikelartikel tersebut ditabulasi dalam tabel yang meliputi nama penulis, judul, tahun terbit, nama jurnal, jenis penelitian dan hasil penelitian. Setelah itu, peneliti mereviu dan menganalisis artikel tersebut secara mendalam terutama mengenai hasil penelitian yang tersaji pada bagian pembahasan dan bagian kesimpulan. Pada bagian akhir penelitian, peneliti membandingkan temuan yang tersaji dalam artikel dan memberi kesimpulan (Sartika \& Octafiani, 2019).

\section{HASIL PENELITIAN DAN PEMBAHASAN}

Kahoot merupakan sebuah alat berbasis permainan yang merupakan hasil dari sebuah proyek penelitian Lecture Quiz yang dimulai pada tahun 2006 di Universitas Sains Norwegia dan Teknologi (NTNU), dimana hasil dari eksperimen prototipe awal menunjukkan hasil yang positif dalam hal peningkatan keterlibatan motivasi, dan persepsi pembelajaran (Qu, Li, Hao, Zhang, \& Yang, 2017; Wang \& Lieberoth, 2016). Kahoot adalah platform pembelajaran berbasis game yang pada awalnya hanya digunakan sebagai teknologi di bidang pendidikan baik di sekolah maupun di lembaga pendidikan lainnya. Namun, sekarang Kahoot bisa digunakan sebagai sarana permainan yang dapat 
mengasah otak yang dapat membantu peserta didik dalam memahami materi pelajaran, meningkatkan keterlibatan dan motivasi, peserta didik lebih fokus, dan umpan balik yang efektif dan reflektif(Ismail \& Mohammad, 2017; Ulimaz, 2019).

Platform pembelajaran berbasis game ini tersedia secara gratis dan telah mendapatkan penerimaan luas secara global dengan lebih dari 30 juta pengguna di seluruh dunia (Ismail \& Mohammad, 2017; Qu et al., 2017). Kahoot menyediakan alat untuk membuat kuis termasuk menambahkan gambar dan Youtube video untuk pertanyaan yang dibuat (Qu et al., 2017). Peserta didik dapat langsung mengetahui skor/poin yang didapatkan dari menjawab pertanyaan. Pembelajaran berbasis game ini memiliki potensi untuk menjadi alat pembelajaran yang efektif karena dapat merangsang komponen visual dan verbal peserta didik (Iwamoto et al., 2017; Sartika \& Octafiani, 2019).

Manfaat penggunaan Kahoot dalam pembelajaran yaitu pemyampaian materi diseragamkan, proses pembelajaran menjadi lebih menarik, proses pembelajaran menjadi lebih interaktif karena adanya unsur AI (Artificial Intelegence) atau terdapat unsur kecerdasan buatan pada media tersebut, kualitas belajar siswa dapat ditingkatkan, dan peran guru menjadi lebih produktif (Muhammad, 2018). Selanjutnya (Bahar et al., 2020) juga mengemukakan bahwa penggunaan Kahoot dapat menjadikan suasana pembelajaran menjadi lebih interaktif dan menyenangkan, dalam proses pembelajaran anakanak dilatih untuk menggunakan teknologi sebai media belajar, dalam pengoperasian Kahoot juga melatih kemampuan motorik peserta didik. Hasil penelitian tentang manfaat penggunaan Kahoot tersaji pada Tabel 1.

Tabel 1 Penelitian tentang Efektifitas Kahoot

\begin{tabular}{|c|c|c|}
\hline Peneliti dan Tahun & Jurnal & Hasil Penelitian \\
\hline (Ulimaz, 2019) & Jurnal Pendidikan Hayati & $\begin{array}{l}\text { Penelitian yang digunakan adalah } \\
\text { penelitian kualitatif yang mengacu } \\
\text { pada game based learning dengan } \\
\text { kesimpulan bahwa dengan } \\
\text { menggunakan aplikasi Kahoot dapat } \\
\text { meningkatkan hasil belajar } \\
\text { mahasiswa. }\end{array}$ \\
\hline (Sururoh, 2020) & 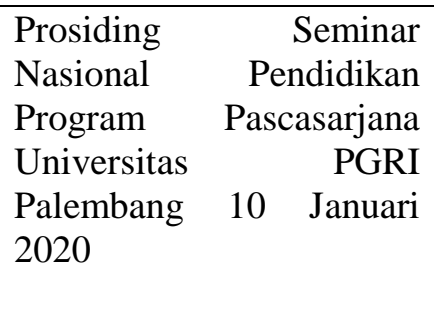 & $\begin{array}{lrr}\text { Penelitian ini } & \text { menggunakan jenis } \\
\text { penulisan } & \text { deskriptif } & \text { dengan } \\
\text { menggunakan pendekatan kualitatif } & \text { dengan kesimpulan } & \text { bahwa } \\
\text { penggunaan } & \text { Kahoot dapat } \\
\text { meningkatkan } & \text { kemampuan berpikir } \\
\text { dan hasil belajar peserta didik. }\end{array}$ \\
\hline (Centauri, 2019) & \begin{tabular}{lrr} 
Seminar & \multicolumn{2}{c}{ Nasional } \\
Pendidikan & MIPA & dan \\
Teknologi & (SNPMT & II) \\
2019 & & \\
"PeningkatanMutu & \\
Pendidikan MIPA & dan \\
Teknologi di & Era \\
RevolusiIndustri & $4.0 "$ \\
Pontianak, 9 September \\
2019
\end{tabular} & $\begin{array}{l}\text { Penelitian ini menggunakan jenis } \\
\text { penelitian kualitatif dan kuantitatif } \\
\text { dengan kesimpulan bahwa } \\
\text { penggunaan Kahoot sebagai media } \\
\text { pembelajaran sangat efektif, } \\
\text { menyenangkan, dan membuat peserta } \\
\text { didik lebih interaktif dalam proses } \\
\text { pembelajaran. }\end{array}$ \\
\hline (Putri \& Muzakki, 2019) & 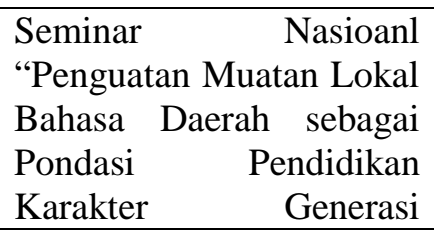 & $\begin{array}{l}\text { Penelitian ini menggunakan jenis } \\
\text { penelitian studi dengan kesimpulan } \\
\text { bahwa Kahoot dapat meningkatkan } \\
\text { motivasi dan kemandirian peserta } \\
\text { didik dan dimanfaatkan untuk }\end{array}$ \\
\hline
\end{tabular}




\begin{tabular}{|c|c|c|}
\hline & $\begin{array}{lll}\text { Milenial" } & \text { Kudus, } & 20 \\
\text { Maret } 2019 & \end{array}$ & $\begin{array}{l}\text { memudahkan dalam proses evaluasi } \\
\text { pembelajaran. }\end{array}$ \\
\hline $\begin{array}{l}\text { (Bahar, } \\
\text { Nurmalia, } \quad \& \quad \text { Astiyaningsih, } \\
\text { 2020) }\end{array}$ & $\begin{array}{lr}\text { KACANEGARA } & \text { Jurnal } \\
\text { Pengabdian } & \text { pada } \\
\text { Masyarakat } & \end{array}$ & $\begin{array}{l}\text { Penelitian ini menggunakan jenis } \\
\text { penelitian kualitatif dengan } \\
\text { kesimpulan bahwa Kahoot dinilai } \\
\text { efektif digunakan sebagai media } \\
\text { pembelajaran berbasis teknologi }\end{array}$ \\
\hline $\begin{array}{l}\text { (Alfansyur \& Mariyani, } \\
\text { 2019) }\end{array}$ & $\begin{array}{l}\text { Jurnal Bhineka Tunggal } \\
\text { Ika }\end{array}$ & $\begin{array}{l}\text { Penelitian ini menggunakan metode } \\
\text { kajian pustaka dengan kesimpulan } \\
\text { bahwa aplikasi Kahoot dapat } \\
\text { meningkatkan semangat belajar } \\
\text { peserta didik. }\end{array}$ \\
\hline $\begin{array}{l}\text { (Jumila, } \quad \text { Paristiowati, } \\
\text { Zulhipri, \& Allanas, 2018) }\end{array}$ & $\begin{array}{ll}\text { Jurnal Riset Pendidikan } \\
\text { Kimia }\end{array}$ & $\begin{array}{l}\text { Penelitian ini menggunakan metode } \\
\text { deskriptif kualitatif dengan } \\
\text { kesimpulan bahwa penggunaan web } \\
\text { Kahoot dalam pembelajaran koloid } \\
\text { dapat menumbuhkan literasi digital } \\
\text { siswa. }\end{array}$ \\
\hline (Mustikawati, 2019) & $\begin{array}{lr}\text { Prosiding } & \text { Seminar } \\
\text { Nasional Bulan } & \text { Bahasa } \\
\text { (Semiba) } 2019 & \end{array}$ & $\begin{array}{l}\text { Pada penelitian ini berkesimpulan } \\
\text { bahwa Kahoot merupakan alternatif } \\
\text { pilihan dari berbagai macam media } \\
\text { pembelajaran interaktif bagi peserta } \\
\text { didik. }\end{array}$ \\
\hline $\begin{array}{l}\text { (Faznur, Khaerunnisa, \& } \\
\text { Sumardi, 2012) }\end{array}$ & $\begin{array}{l}\text { Jurnal } \quad \text { Pengabdian } \\
\text { Masyarakat Teknik }\end{array}$ & $\begin{array}{l}\text { Penelitian ini menggunakan metode } \\
\text { kualitatif dan kuantatif dengan } \\
\text { kesimpulan bahwa aplikasi Kahoot } \\
\text { mendapat respon yang positif dari } \\
\text { peserta. }\end{array}$ \\
\hline (Fauzan, 2019) & $\begin{array}{lr}\text { Prosiding } & \text { Seminar } \\
\text { Nasional } & \text { Pendidikan } \\
\text { FKIP Untirta } & \end{array}$ & $\begin{array}{l}\text { Penelitian ini menggunakan metode } \\
\text { kualitatif dengan kesimpulanbahwa } \\
\text { penggunaan Kahoot sebagai media } \\
\text { pembelajaran sangat menyenangkan, } \\
\text { interaktif, menarik, dan efektif dalm } \\
\text { proses pembelajaran. }\end{array}$ \\
\hline $\begin{array}{l}\text { (Ilmiyah \& Sumbawati, } \\
\text { 2019) }\end{array}$ & $\begin{array}{lr}\text { Journal } & \text { Information } \\
\text { Engineering } & \text { and } \\
\text { Educational Technology }\end{array}$ & $\begin{array}{l}\text { Penelitian ini menggunakan } \\
\text { penelitian eksperimen dengan desain } \\
\text { faktor } 2 \times 2 \text { dengan kesimpulan bahwa } \\
\text { dengan menggunakan Kahoot } \\
\text { sebagai media pembelajaran dapat } \\
\text { memotivasi siswa dalam proses } \\
\text { pembelajaran. }\end{array}$ \\
\hline (Khomsah \& Imron, 2020) & $\begin{array}{ll}\text { Tarbiyatuna: } & \text { Jurnal } \\
\text { Pendidikan Ilmiah } & \end{array}$ & $\begin{array}{l}\text { Kajian ini menggunakan metode } \\
\text { studi literatur dengan kesimpulan } \\
\text { bahwa menggunakan aplikasi Kahoot } \\
\text { dapat meningkatkan kualitas dari } \\
\text { pembelajaran. }\end{array}$ \\
\hline $\begin{array}{l}\text { (Mafruhah, Sulistiani, \& } \\
\text { Mustafida, 2019) }\end{array}$ & $\begin{array}{ll}\text { VICRATINA: } & \text { Jurnal } \\
\text { Pendidikan Islam } & \end{array}$ & $\begin{array}{l}\text { Penelitian ini menggunakan jenis } \\
\text { penelitian kualitatif dengan } \\
\text { kesimpulan bahwa penggunaan } \\
\text { aplikasi Kahoot berpengaruh } \\
\text { terhadap hasil belajar peserta didik, } \\
\text { dalam artian penggunaan Kahoot } \\
\text { lebih efektif. }\end{array}$ \\
\hline
\end{tabular}




\begin{tabular}{|c|c|c|}
\hline (Suyidno et al., 2019) & $\begin{array}{l}\text { Bubungan Tinggi: Jurnal } \\
\text { Pengabdian Masyarakat }\end{array}$ & 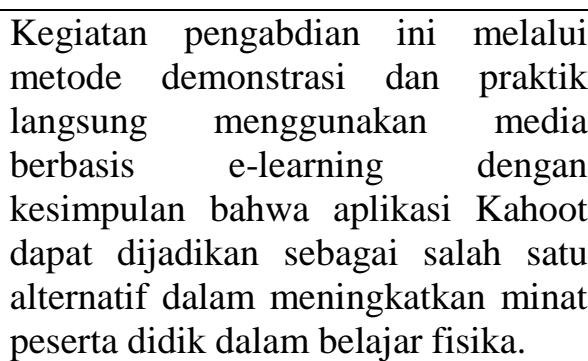 \\
\hline (Muhammad, 2018) & $\begin{array}{l}\text { Journal Civics \& Social } \\
\text { Studies }\end{array}$ & $\begin{array}{l}\text { Penelitian ini menggunakan desain } \\
\text { penelitian kualitatif dan model } \\
\text { eksperimen True Eksperimental } \\
\text { dengan kesimpulan bahwa terdapat } \\
\text { pengaruh yang signifikan antara } \\
\text { penggunaan aplikasi Kahoot dengan } \\
\text { peningkatan minat mata pelajaran } \\
\text { PKn. }\end{array}$ \\
\hline (Irwan, 2019) & $\begin{array}{lll}\text { Journal of } & \text { Civic } \\
\text { Education } & & \end{array}$ & $\begin{array}{l}\text { Penelitian ini menggunakan metode } \\
\text { campuaran (mixed method) antara } \\
\text { kualitatif dan metode kuantitatif } \\
\text { dengan kesimpulan bahwa Kahoot } \\
\text { efektif sebagai media pembelajaran } \\
\text { dalam menunjang proses belajar dan } \\
\text { mengajar. }\end{array}$ \\
\hline (Ningrum, 2018) & $\begin{array}{l}\text { VOX EDUKASI: Jurnal } \\
\text { Ilmiah Ilmu Pendidikan }\end{array}$ & $\begin{array}{l}\text { Penelitian ini menggunakan } \\
\text { penelitian eksperimen semu dengan } \\
\text { kesimpulan bahwa hasil belajar } \\
\text { mahasiswa dengan penggunaan } \\
\text { media kuis interaktif berbasis game } \\
\text { edukasi kahoot lebih baik } \\
\text { dibandingkan menggunakan media } \\
\text { kuis berbasis powerpoint. }\end{array}$ \\
\hline (Martikasari, 2018) & 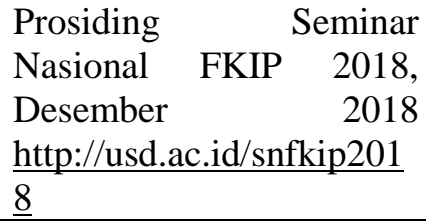 & $\begin{array}{l}\text { Penelitian ini menggunakan jenis } \\
\text { penelitian deskriptif kuantitatif } \\
\text { dengan kesimpulan bahwa Kahoot } \\
\text { dapat digunakan sebagai media } \\
\text { pembelajaran interaktif alternatif. }\end{array}$ \\
\hline $\begin{array}{l}\text { (Kompetitif, Kolaboratif, } \\
\text { Rofiyarti, \& Sari, 2017) }\end{array}$ & $\begin{array}{l}\text { PEDAGOGI: Jurnal Anak } \\
\text { Usia Dini dan Pendidikan } \\
\text { Anak Usia Dini }\end{array}$ & $\begin{array}{l}\text { Desain permainan dalam "Kahoot!" } \\
\text { yang bersifat multiplayer } \\
\text { memungkinkan anak untuk dapat } \\
\text { berkolaborasi sekaligus berkompetisi } \\
\text { melalui permainan yang interaktif. } \\
\text { Aktivitas yang dilakukan dengan } \\
\text { menggunakan platform ini dapat } \\
\text { memfasilitasi interaksi sosial anak } \\
\text { sehingga kecenderungan terjadinya } \\
\text { kecanduan terhadap teknologi } \\
\text { (gadget addict) dapat dikurangi. }\end{array}$ \\
\hline
\end{tabular}

Berdasarkan hasil penelitian yang telah dilakukan sebagaimana tercantum pada Tabel 1, penggunaan Kahoot ternyata terbukti dapat meningkatkan hasil belajar peserta didik (Ulimaz, 2019), meningkatkan kemampuan berpikir dan hasil belajar (Sururoh, 2020), berpengaruh terhadap hasil belajar dalam artian penggunaan Kahoot lebih efektif dalam proses pembelajaran (Mafruhah, Sulistiani, \& Mustafida, 2019), dan efektif sebagai media pembelajaran berbasis teknologi (Bahar, 
Setiyaningsih, Nurmalia, \& Astriani, 2020). Selain itu, Kahoot juga dapat memotivasi siswa dalam pembelajaran (Ilmiyah \& Sumbawati, 2019), sehingga dapat meningkatkan semangat belajar peserta didik (Alfansyur \& Mariyani, 2019), meningkatkan motivasi dan kemandirian belajar (Putri \& Muzakki, 2019) dan meningkatkan kualitas pembelajaran (Khomsah \& Imron, 2020).

Kahoot juga mendapatkan respon yang positif dari peserta didik (Faznur, Khaerunnisa, \& Sumardi, 2012). Dikarenakan Kahoot merupakan media pembelajaran yang efektif, menyenangkan, yang dapat membuat peserta didik lebih interaktif dalam proses pembelajaran (Centauri, 2019). Selanjutnya, (Fauzan, 2019) dan (Irwan, 2019) juga menyimpulkan bahwa Kahoot merupakan media pembelajaran yang menyenangkan, interaktif, menarik, dan efektif untuk mendukung proses pembelajaran. Bukan hanya efektif pada mata pelajaran matematika, ternyata Kahoot juga efektif digunakan pada mata pelajaran lain. Seperti pada mata pelajaran PKn, ternyata penggunaan Kahoot memiliki pengaruh yang signifikan terhadap mata pelajaran PKn (Muhammad, 2018), Kahoot juga dapat digunakan sebagai alternatif media pembelajaran yang dapat meningkatkan minat peserta didik dalam belajar Fisika (Suyidno et al., 2019), dan dapat menumbuhkan literasi digital siswa dalam pembelajaran koloid (Jumila, Paristiowati, Zulhipri, \& Allanas, 2018). Untuk memaksimalkan hasil pembelajaran, penggunaan Kahoot dapat dipadukan dengan pendekatan, strategi, model, dan metode pembelajaran tertentu sebagaimana hasil penelitian pada Tabel 2.

Tabel 2 Penerapan Kahoot Bersama Model, Metode Pembelajaran Tertentu

\begin{tabular}{|c|c|c|}
\hline Penulis & Jurnal & Hasil Penelitian \\
\hline (Izzati \& Kuswanto, 2019) & $\begin{array}{l}\text { EDUMATIC: Jurnal Pendidikan } \\
\text { Informatika }\end{array}$ & $\begin{array}{l}\text { Penelitian ini menggunakan } \\
\text { jenis penelitian kuantitatif } \\
\text { dengan metode eksperimen } \\
\text { dengan kesimpulan bahwa } \\
\text { model pembelajaran Blanded } \\
\text { Learning rengan } \\
\text { menggunakan } \\
\text { memiliki pengaruh secara } \\
\text { signifikan } \\
\begin{array}{ll}\text { kemandirian, dan } \\
\text { belajar siswa. }\end{array}\end{array}$ \\
\hline (Nugraha, 2018) & $\begin{array}{l}\text { UJMES (Uninus Journal of } \\
\text { Mathematics Education and } \\
\text { Science) }\end{array}$ & $\begin{array}{l}\text { Penelitian ini menggunakan } \\
\text { penelitian tindakan kelas } \\
\text { dengan kesimpulan bahwa } \\
\text { pembelajaran teknik STAD } \\
\text { berbantuan Kahoot dapat } \\
\text { meningkatkan kemampuan } \\
\text { pemahaman masalah } \\
\text { matematika siswa. }\end{array}$ \\
\hline $\begin{array}{l}\text { (Wijayanti, Hermanto, \& } \\
\text { Zainuddin, 2019) }\end{array}$ & Sigma & $\begin{array}{l}\text { Penelitian ini menggunakan } \\
\text { jenis penelitian quasi } \\
\text { eksperiment (eksperimen } \\
\text { semu) dengan kesimpulan } \\
\text { bahwa pendekatan Realistic } \\
\text { Mathematic Education } \\
\text { (RME) dengan berbantuan } \\
\text { media pembelajaran aplikasi } \\
\text { kahoot efektif digunakan } \\
\text { dalam proses pembelajaran } \\
\text { matematika. }\end{array}$ \\
\hline
\end{tabular}




\begin{tabular}{|l|lr|l|}
\hline Tembang, Purwanty, \& & $\begin{array}{l}\text { Premiere Educandum : Jurnal } \\
\text { Pendidikan Dasar dan } \\
\text { Pembelajaran }\end{array}$ & $\begin{array}{l}\text { Penelitian ini menggunakan } \\
\text { jenis penelitian tindakan kelas } \\
\text { dengan kesimpulan bahwa } \\
\text { dengan menggunakan media } \\
\text { think pair share berbantuan }\end{array}$ \\
& & $\begin{array}{l}\text { Kahoot dapat meningkatkan } \\
\text { keaktifan mahasiswa dalam } \\
\text { proses pembelajaran. }\end{array}$ \\
\hline
\end{tabular}

Beberapa hasil penelitian pada Tabel 2 mengungkapkan bahwa Kahoot efektif jika dipadukan dengan penggunaan model dan metode pembelajaran tertentu seperti model dan memiliki pengaruh yang signifikan terhadap kemandirian, dan motivasi siswa (Izzati \& Kuswanto, 2019), teknik STAD sehingga dapat meningkatkan kemampuan pemahaman masalah matematika siswa (Nugraha, 2018), pendekatan Realistic Mathematic Education (RME) dengan berbantuan media pembelajaran aplikasi kahoot efektif digunakan dalam proses pembelajaran matematika (Wijayanti, Hermanto, \& Zainuddin, 2019), dan dengan menggunakan media think pair share berbantuan Kahoot untuk meningkatkan keaktifan mahasiswa dalam proses pembelajaran (Tembang, Purwanty, \& Hermansyah, 2020). Selain itu, penggunaan Kahoot juga telah diupayakan melalui penelitian pengembangan sebagaimana tersaji pada Tabel 3.

Tabel 3 Hasil Penelitian Pengembangan Aplikasi Kahoot

\begin{tabular}{|c|c|c|}
\hline Peneliti dan Tahun & Jurnal & Hasil Penelitian \\
\hline (Sartika \& Octafiani, 2019) & Journal On Education & $\begin{array}{lrr}\text { Penelitian yang } & \text { digunakan } \\
\text { adalah metode penelitian dan } \\
\text { pengembangan (Research and } \\
\text { Development) } & \text { dengan } \\
\text { kesimpulan } & \text { alat } & \text { evaluasi } \\
\text { dengan } & \text { menggunakan } \\
\text { aplikasi } & \text { kahoot } & \text { layak } \\
\text { digunakan } & & \text { untuk } \\
\text { meningkatkan } & \text { pembelajaran } \\
\text { matematika. } & & \end{array}$ \\
\hline (Andari, 2020) & $\begin{array}{l}\text { ORBITA: Jurnal } \quad \text { Kajian, } \\
\text { Inovasi dan Aplikasi Pendidikan } \\
\text { Fisika }\end{array}$ & $\begin{array}{l}\text { Penelitian ini menggunakan } \\
\text { penelitian pengembangan } \\
\text { (R\&D) dengan kesimpulan } \\
\text { bahwa hasil belajar } \\
\text { mahasiswa } \\
\text { memanfaatkan media game } \\
\text { edukasi kahoot lebih baik } \\
\text { dibandingkan dengan } \\
\text { kelompok mahasiswa yang } \\
\text { menggunakan power point. }\end{array}$ \\
\hline $\begin{array}{l}\text { (Ulya, Laily, \& Hakim, } \\
\text { 2020) }\end{array}$ & $\begin{array}{l}\text { Jurnal of Islamic Religius } \\
\text { Education }\end{array}$ & $\begin{array}{lr}\text { Penelitian ini } & \text { menggunakan } \\
\text { metode } & \text { penelitian } \\
\text { pengembangan } & \text { (R\&D) } \\
\text { dengan kesimpulan } \text { bahwa } \\
\text { pembelajaran } & \text { yang } \\
\text { menggunakan } & \text { multimedia } \\
\text { dapat } & \text { menciptakan } \\
\text { pembelajaran yang menarik } \\
\text { dan membuat siswa lebih } \\
\text { aktif baik } & \text { dengan }\end{array}$ \\
\hline
\end{tabular}




\begin{tabular}{|l|l|l|}
\hline & & $\begin{array}{l}\text { menggunakan Pop up, } \\
\text { Kahoot, Video Explanasi } \\
\text { yang merupakan } \\
\text { implementasi dari kolaborasi } \\
\text { media. }\end{array}$ \\
\hline (Jannah \& Pahlevi, 2020) & $\begin{array}{l}\text { Jurnal Pendidikan Administrasi } \\
\text { Perkantoran (JPAP) }\end{array}$ & $\begin{array}{l}\text { Penelitian ini menggunakan } \\
\text { jenis } \\
\text { pengembangan penelitian } \\
\text { dengan kesimpulan bahwa } \\
\text { dengan menggunakan Kahoot } \\
\text { rata-rata kemampuan berpikir } \\
\text { tingkat tinggi siswa berada } \\
\text { pada kategori "baik" dan } \\
\text { tanggapan siswa "sangat } \\
\text { postif" terhadap aplikasi } \\
\text { Kahoot. }\end{array}$ \\
\hline
\end{tabular}

Pada Tabel 3, penggunaan Kahoot dalam beberapa penelitian telah diupayakan melalui pengembangan terhadap Aplikasi Kahoot. Pada penelitian Sartika \& Octafiani (2019), dihasilkan Kahoot yang layak digunakan untuk meningkatkan pembelajaran matematika. Selain itu, hasil belajar mahasiswa yang menggunakan media game edukasi Kahoot lebih baik dibandingkan dengan kelompok mahasiswa yang menggunakan power point (Andari, 2020). Selanjutnya, Jannah \& Pahlevi (2020) mengemukakan bahwa siswa yang menggunakan Kahoot rata-rata kemampuan berpikir tingkat tinggi siswa berada pada kategori "baik" dan tanggapan siswa "sangat positif" terhadap aplikasi Kahoot. Sedangkan pada penelitian (Ulya, Laily, \& Hakim, 2020) menjelaskan bahwa pembelajaran yang menggunakan multimedia dapat menciptakan pembelajaran yang menarik dan membuat siswa lebih aktif baik dengan menggunakan Pop up, Kahoot, Video Explanasi yang merupakan implementasi dari kolaborasi media.

Beberapa hal yang perlu diperhatikan dalam penggunaan Kahoot antara lain tidak diperlukan perangkat hardware dan software tertentu dalam penggunaannya, dan dapat diakses secara gratis (Jannah \& Pahlevi, 2020; Putri \& Muzakki, 2019), serta tidak semua guru paham dengan teknologi dan memiliki waktu untuk menyusun rancangan pembelajaran menggunakan Kahoot. Selain itu, diperlukan fasilitas internet yang memadai dan diharapakan siswa memiliki smartphone ataupun laptop (Bahar et al., 2020; Putri \& Muzakki, 2019).

\section{KESIMPULAN}

Penggunaan aplikasi Kahoot sangat layak digunakan pada proses pembelajaran matematika secara daring. Hal ini dikarenakan dengan menggunakan aplikasi Kahoot dapat meningkatkan hasil belajar peserta didik, meningkatkan kemampuan berpikir, dan motivasi peserta didik. Hal ini karena aplikasi Kahoot dapat digunakan sebagai media pembelajaran kuis interaktif yang sangat efektif, menyenangkan, dan membuat peserta didik lebih bersemangat dalam pembelajaran.

\section{REFERENCES}

Abidin, Z., Rumansyah, \& Arizona, K. (2020). Pembelajaran Online Berbasis Proyek Salah Satu Solusi Kegiatan Belajar Mengajar Di Tengah Pandemi Covid-19. Jurnal Ilmiah Profesi Pendidikan, 5(1), 64-70. https://doi.org/10.29303/jipp.v5i1.111

Afifah, D. S. N. (2012). Interaksi Belajar Matematika Siswa Dalam Pembelajaran Kooperatif Tipe STAD. PEDAGOGIA: Jurnal Pendidikan, 1(2), 145. https://doi.org/10.21070/pedagogia.vli2.37 Alessandro, B. (2018). Digital skills and competence, and digital and online learning. In

$\begin{array}{llll}\text { TurinEuropean } & \text { Training } & \text { Foundation. } & \text { Retrieved }\end{array}$


https://www.etf.europa.eu/sites/default/files/2018-10/DSC and DOL_0.pdf

Alfansyur, A., \& Mariyani. (2019). Pemanfaatan Media Berbasis Ict "Kahoot" Dalam Pembelajaran Ppkn Untuk Meningkatkan Motivasi Belajar Siswa. Bhineka Tunggal Ika: Kajian Teori Dan Praktik Pendidikan PKn, 6(2), 208-216. https://doi.org/10.36706/jbti.v6i2.10118

Andari, R. (2020). Pemanfaatan Media Pembelajaran Berbasis Game Edukasi Kahoot! Pada Pembelajaran Fisika. ORBITA: Jurnal Kajian, Inovasi Dan Aplikasi Pendidikan Fisika, 6(1), 135. https://doi.org/10.31764/orbita.v6i1.2069

Bahar, H., Setiyaningsih, D., Nurmalia, L., \& Astriani, L. (2020). Efektifitas Kahoot Bagi Guru Dalam Pembelajaran. KACANEGARA Jurnal Pengabdian Pada Masyarakat, 3(2), 155-162. https://doi.org/10.28989/kacanegara.v3i2.677

Betyka, F., Putra, A., \& Erita, S. (2019). Pengembangan Lembar Aktivitas Siswa Berbasis Penemuan Terbimbing pada Materi Segitiga. JURING (Journal for Research in Mathematics Learning), 2(2), 179. https://doi.org/10.24014/juring.v2i2.7684

Centauri, B. (2019). Efektivitas Kahoot! Sebagai Media Pembelajaran Kuis Interaktif Di Sdn-7 Bukit

Tunggal. Prosiding Seminar Nasional Pendidikan Mipa Dan Teknologi Ii, 1(1), 124-133.

Dewi, W. A. F. (2020). Dampak COVID-19 terhadap Implementasi Pembelajaran Daring di Sekolah Dasar. Edukatif: Jurnal Ilmu Pendidikan, 2(1), 55-61. https://doi.org/10.31004/edukatif.v2i1.89

Fauzan, R. (2019). Pemanfaatan Gamification Kahoot.it Sebagai Enrichment Kemampuan Berfikir Historis Mahasiswa pada Mata Kuliah Sejarah Kolonialisme Indonesia. Prosiding Seminar Nasional Pendidikan FKIP UNTIRTA, 2(1), 257. Retrieved from http://jurnal.untirta.ac.id/index.php/psnp/article/view/5764

Faznur, L. S., Khaerunnisa, \& Sumardi, A. (2012). Aplikasi Kahoot Sebagai Media Evaluasi Pembelajaran Bahasa Indonesia Pada Guru SMA di Sukabumi. Jurnal Pengabdian Masyarakat Teknik, 8(2), 1-9. https://doi.org/10.24853/jpmt.2.2.39-44

Fitriyani, Y., Fauzi, I., \& Sari, M. Z. (2020). Motivasi Belajar Mahasiswa Pada Pembelajaran Daring Selama Pandemik Covid-19. Jurnal Kependidikan: Jurnal HAsil Penelitian Dan Kajian Kepustakaan Di Bidang Pendidikan, Pengajaran Dan Pembelajaran, 6(2), 165-175. https://doi.org/10.23917/ppd.v7i1.10973

Handarini, O. I., \& Wulandari, S. S. (2020). Pembelajaran Daring Sebagai Upaya Study From home (SFH) Selama Pandemi Covid 19. Jurnal Pendidikan Administrasi Perkantoran (JPAP), 8(1), 496-503.

Hasanah, Q. (2020). Pemanfaatan Aplikasi Whastapp sebagai Media E-Learning Masa Covid-19 pada Mata Kuliah Biomolekul dan Metabolisme di Tadris IPA IAIN Bengkulu. Indonesia Science Education Jurnal, 1(3), 225-236.

Ilmiyah, N. H., \& Sumbawati, M. S. (2019). Pengaruh Media Kahoot Dan Motivasi Belajar Terhadap Hasil Belajar Siswa. Journal Information Engineering and Educational Technology, 3(1), 47. Retrieved from https://journal.unesa.ac.id/index.php/jieet/article/view/5086/pdf

Irwan. (2019). Implementasi Kahoot Sebagai Inovasi Pembelajaran. Journal of Civic Education, 2(2), 126-140. Retrieved from http://repositorio.unan.edu.ni/2986/1/5624.pdf

Ismail, M. A.-A., \& Mohammad, J. A.-M. (2017). Kahoot: A Promising Tool for Formative Assessment in Medical Education. Education in Medicine Journal, 9(2), 19-26. https://doi.org/10.21315/eimj2017.9.2.2

Iwamoto, D. H., Hargis, J., Taitano, E. J., \& Vuong, K. (2017). Analyzing the efficacy of the testing effect using Kahoot ${ }^{\mathrm{TM}}$ on student performance. Turkish Online Journal of Distance Education, 18(2), 80-93.

Izzati, M., \& Kuswanto, H. (2019). Pengaruh Model Pembelajaran Blanded Learning berbantuan Kahoot terhadap Motivasi dan Kemandirian Siswa. EDUMATIC: Jurnal Pendidikan Informatika, 3(2), 65-75. https://doi.org/10.29408/edumatic.v3i2.1656 
Jannah, K., \& Pahlevi, T. (2020). Pengembangan Instrumen Penilaian Berbasis Higher Order Thinking Skills Berbantuan Aplikasi “ Kahoot!” Pada Kompetensi Dasar Menerapkan Penanganan Surat Masuk dan Surat Keluar Jurusan OTKP di SMK Negeri 2 Buduran. Jurnal Pendidikan Administrasi Perkantoran (JPAP), 8(1), 108-121.

Jumila, Paristiowati, M., Zulhipri, Z., \& Allanas, E. (2018). Analisis Literasi Digital (ICT) Peserta Didik Melalui Pemanfaatan Web Kahoot dalam Pembelajaran Koloid. Jurnal Riset Pendidikan Kimia, 8(2), 36-41. https://doi.org/10.21009/jrpk.082.04

Khomsah, A. F., \& Imron, M. (2020). Pembelajaran Bahasa Arab Melalui Kolaborasi Metode Questioning dan Media Kahoot. Tarbiyatuna: Jurnal Pendidikan Ilmiah, 5(1), 99-118.

Kompetitif, J., Kolaboratif, D., Rofiyarti, A. F., \& Sari, A. Y. (2017). PEDAGOGI: Jurnal Anak Usia Dini dan Pendidikan Anak Usia Dini. PEDAGOGI: Jurnal Anak Usia Dini Dan Pendidikan Anak Usia Dini, 3(3b), 164-172. Retrieved from https://kahoot.com/

Lin, C. S., \& Wu, R. Y. W. (2016). Effects of Web-Based creative thinking teaching on students' creativity and learning outcome. Eurasia Journal of Mathematics, Science and Technology Education, 12(6), 1675-1684. https://doi.org/10.12973/eurasia.2016.1558a

Lin, M. H., Chen, H. C., \& Liu, K. S. (2017). A study of the effects of digital learning on learning motivation and learning outcome. Eurasia Journal of Mathematics, Science and Technology Education, 13(7), 3553-3564. https://doi.org/10.12973/eurasia.2017.00744a

Lin, Y. W., Tseng, C. L., \& Chiang, P. J. (2017). The effect of blended learning in mathematics course. Eurasia Journal of Mathematics, Science and Technology Education, 13(3), 741-770. https://doi.org/10.12973/eurasia.2017.00641a

Mafruhah, S., Sulistiani, I. R., \& Mustafida, F. (2019). Pengaruh Penggunaan Media Pembelajaran Interaktif Berbasis Aplikasi (Kahoot) Terhadap Hasil Belajar Siswa Kelas XI di SMAI AlMaarif Singosari Malang. VICRATINA: Jurnal Pendidikan Islam, 3(7), 23-29.

Martikasari, K. (2018). Kahoot: Media Pembelajaran Interaktif Dalam Era Revolusi Industri 4.0. Prosiding Seminar Nasional FKIP 2018, Desember 2018 Http://Usd.Ac.Id/Snfkip2018, 181-189. https://doi.org/10.24071/snfkip.2018.19

Melinda, N., \& Lazwardi, A. (2020). KEMAMPUAN DISPOSISI MATEMATIS SISWA PADA PEMBELAJARAN DARING DI MASA PANDEMI COVID-19. Konferensi Nasional Pendidikan I, 59-65.

Muhammad, Y. M. (2018). Implementation of Kahoot Application To Improving of Interest Civic Education Learning (Experimental, Research, in Class XI of SMA Negeri 1 Garut). Journal Civics \& Social Studies, 2(1), 75-92.

Mustakim. (2020). Efektivitas Pembelajaran Daring Menggunakan Media Online Selama Pandemi Covid-19 Pada Mata Pelajaran Matematika the Effectiveness of E-Learning Using Online Media During the Covid-19 Pandemic in Mathematics. Al Asma: Journal of Islamic Education, 2(1), 112.

Mustikawati, F. E. (2019). Fungsi Aplikasi Kahoot sebagai Media Pembelajaran Bahasa Indonesia. Prosiding Seminar Nasional Bulan Bahasa (Semiba) 2019, 0, 2019. Retrieved from https://semcon.unib.ac.id/index.php/semiba/Semiba/schedConf/presentations

Ningrum, G. D. K. (2018). Studi Penerapan Media Kuis Interaktif Berbasis Game Edukasi Kahoot! Terhadap Hasil Belajar Mahasiswa. VOX EDUKASI: Jurnal Ilmiah Ilmu Pendidikan, 9(1), 2227. https://doi.org/10.31932/ve.v9i1.32

Nugraha, H. (2018). Meningkatkan pemahaman Matematika Siswa SMP Negeri 1 Pagaden Kelas VIII dengan Gamification Kahoot. UJMES (Uninus Journal of Mathematics Education and Science), $3(1), 148-154$.

Nurhayati, E. (2020). Meningkatkan Keaktifan Siswa Dalam Pembelajaran Daring Melalui Media Game Edukasi Quiziz Pada Masa Pencegahahan Penyebaran Covid-19. Jurnal Paedagogy: 
Jurnal Penelitian Dan Pengembangan Pendidikan, 7(3), 145-150. https://doi.org/https://doi.org/10.33394/jp.v7i3.2645

Patimah, S., Lyesmaya, D., \& Maula, L. H. (2020). Analisis Aktivitas Pembelajaran Matematika pada Materi Pecahan Campuran Berbasis Daring ( Melalui Aplikasi Whatsapp ) di Masa Pandemi Covid-19 pada Siswa Kelas 4 SD Pakujajar CBM. Jurnal Kajian Pendidikan Dasar, 5(2), 98105.

Purwasih, R., Aripin, U., \& Fitrianna, A. Y. (2018). Implementasi Pembelajaran Worksheet Berbasis ICT Untuk Peningkatan Kemampuan High Order Mathematical Thinking (HOMT) Siswa SMP. JIPM (Jurnal Ilmiah Pendidikan Matematika), 7(1), 57. https://doi.org/10.25273/jipm.v7i1.3841

Putri, A. R., \& Muzakki, M. A. (2019). Implemetasi Kahoot sebagai Media Pembelajaran Berbasis Digital Game Based Learning dalam Mengahadapi Era Revolusi Industri 4.0. Prosiding Seminar Nasional Universitas Muria Kudus, 1-7. Retrieved from http://pgsd.umk.ac.id/files/prosiding/2019/27_Aprilia_Riyana.pdf

Qu, C., Li, H., Hao, S., Zhang, X., \& Yang, W. (2017). Perceptions of Students for Gamification Approach: Kahoot as a Case Study. AIP Conference Proceedings, 1890, 72-93. https://doi.org/10.1063/1.5005217

Rigianti, H. A. (2020). Kendala Pembelajaran Daring Guru Sekolah Dasar di Kabupaten Banjarnegara. Elementary School, 7(2), 297-302.

Rosyid, N. M., Thohari, I., \& Lismanda, Y. F. (2020). Penggunaan Aplikasi Zoom Cloud Meetings dalam Kuliah Statistik Pendidikan di Fakultas Agama Islam Universitas Islam Malang. Pendidikan Islam, 5(1), 1-5.

Sartika, \& Octafiani, M. (2019). Pemanfaatan Kahoot Untuk Pembelajaran Matematika Siswa Kelas X Pada Materi Sistem Persamaan Linear Dua Variabel. Journal On Education, 01(03), 373-385.

Sintema, E. J. (2020). Effect of COVID-19 on the performance of grade 12 students: Implications for STEM education. Eurasia Journal of Mathematics, Science and Technology Education, 16(7), 1-6. https://doi.org/10.29333/EJMSTE/7893

Siregar, N. R. (2017). Persepsi Siswa Pada Pelajaran Matematika: Studi Pendahuluan Pada Siswa yang Menyenangi Game. Prosiding Temu Ilmiah X Ikatan Psikologi Perkembangan Indonesia, 224-232.

Suhery, Putra, T. J., \& Jasmalinda. (2020). Sosialisasi Penggunaan Aplikasi Zoom Meeting dan Google Classroom Pada Guru di SDN 17 Mata Air Padang Selatan. Jurnal Inovasi Penelitian, $1(3), 1-4$.

Sururoh, L. (2020). Prosiding seminar nasional pendidikan program pascasarjana universitas pgri palembang 10 januari 2020. 496-506.

Suyidno, S., Zainuddin, Z., Misbah, M., Salam, A., Mastuang, M., Sasmita, F. D., ... Ramadhan, R. (2019). Pelatihan Media Berbasis E-learning Menggunakan Kahoot! untuk Guru Fisika. Bubungan Tinggi: Jurnal Pengabdian Masyarakat, $1(1), \quad 9$. https://doi.org/10.20527/btjpm.v1i1.1779

Syarifudin, A. S. (2020). Implementasi Pembelajaran Daring Untuk Meningkatkan Mutu Pendidikan Sebagai Dampak Diterapkannya Social Distancing. Jurnal Pendidikan Bahasa Dan Sastra Indonesia Pemerintah, 5(1), 31-34.

Tembang, Y., Purwanty, R., \& Hermansyah, A. K. (2020). Implementasi model think pair share berbantuan media Kahoot It meningkatkan keaktifan berdisikusi mahasiswa. Premiere Educandum: Jurnal Pendidikan Dasar Dan Pembelajaran, 10(1), 22. https://doi.org/10.25273/pe.v10i1.5368

Triandini, E., Jayanatha, S., Indrawan, A., Putra, G. W., \& Iswara, B. (2019). Metode Systematic Literature Review untuk Identifikasi Platform dan Metode Pengembangan Sistem Informasi di Indonesia. IJIS: Indonesian Journal of Information Systems, 1(2), 63-77. 
Ulimaz, A. (2019). Hasil Belajar Mahasiswa Prodi DIII Agroindustri Pada Materi Parameter Limbah Cair Menggunakan Media Pembelajaran Kahoot. Jurnal Pendidikan Hayati, 5(4), 157-163.

Ulya, H., Laily, N. H., \& Hakim, M. L. (2020). Pengembangan Media Pembelajaran Pai Dengan menggunakan video explanasi, po up, dan kahoot. Jurnal of Islamic Religius Education, 4(1), 39-48.

Wang, A. I., \& Lieberoth, A. (2016). Effect of Points and Audio in Kahoot. European Conference on Games Based Learning, Academic C, 738.

Wibawanto, W. (2017). Desain dan Pemrogaman Multimedia Pembelajaran Interaktif. Jawa Timur: Cerdas Ulet Kreatif.

Wijayanti, R., Hermanto, D., \& Zainuddin. (2019). Efektivitas Penggunaan Pendekatan Pembelajaran Realistic Mathematic Education (Rme) Dengan Berbantuan Media Pembelajaran Aplikasi Kahoot. Sigma, 4(3), 1. https://doi.org/10.36513/sigma.v4i3.640 